資料

図形知覚における発達曲線の比較的考察 II*

一一図形の特質と知能の分析—

一一静岡大学 勝 井晃 ${ }^{* *}$

\section{I 実験目的}

前出資料(2) 飞和いて明らかなように，同一図形選択 飞和汗る正確度の発達曲線は, その図形の形態や選択条 件によって，それぞれ異なるが成人の正確度に対する， 各年令段階の相対的正確度 $(\%)$ の界率は極めて近似の 発達的変化を示するのであった。

しかし，その曲線を規定する諸条件のうち，同一図形 選択の cue となる図形の属性, すなわち形態的特質, 大小, 方向性等によって, 正確度の絶対値がそれぞれ異 なる点が問題として残され，かつ発達的変化を規定する 被験者の側の諸要因のらち, 最も大きなものとして, 幼 児の知的発達と正確度との関係が不明確であった。本稿 飞频いては, この点を吟味するために, 次の 3 点につい て実験考察を行なった.

（1）図形を, 形態, 大小, 方向の違いを持った 3 群 に分け，同一被験者群に同時的に行ない，それら各群に おける正確度を比較検討する。

（2）上群の図形を，正常児拉よび精薄児両群に行な い, その知能発達段階に掠ける正確度と知能との相関お よび両被験者群の比較を行なう。

（3）（1）(2)飞和ける図形知覚の特質と発達曲線の 変化を吟味し，曲線を規定する諸要因についてさらに分 析を行なら。

\section{II 実験方法}

Fig. 1 の形態, 大小, 方向の 3 群 の図形を 1 群ずつ ランダムに並列に呈示し（此較図形）, 標準図形は, 前 実駼 $(2)$ 飞同様の刺激呈示板の上部空飞 1 個ずつランダ ム飞呈示して下部空の比較図形群の中から同一図形と思 われるるのを選択させる.な抗この場合「同じものを選 べ」という instruction の意味については, 各図形群ご とに本実験に入る前, 比較図形群にない近似のサンプル を 2 枚ずつ呈示し，“かたち” “大きさ”“方向”の「同じ」 の意味について 2 度説明する. 乙かし，その意味を被験 者がどの程度正確に理解したかについては検証せず，た だちに本実験に入る。

* Curves of Development in Figure Perception II

** Akira Katsui (Shizuoka Univeritys).
Table 1

\begin{tabular}{|c|c|c|c|c|c|c|}
\hline C. A. & $\begin{array}{c}3: 0 \\
?^{3}: 11\end{array}$ & $\begin{array}{c}4: 0 \\
?: 11 \\
4: 1\end{array}$ & $\begin{array}{c}5: 0 \\
5: 11 \\
5\end{array}$ & $\begin{array}{c}6: 0 \\
?: 11 \\
6: 11\end{array}$ & $\begin{array}{c}7: 0 \\
7: 11 \\
7\end{array}$ & Total \\
\hline$N$ & 30 & 30 & 30 & 30 & 30 & 150 \\
\hline
\end{tabular}

Table 2

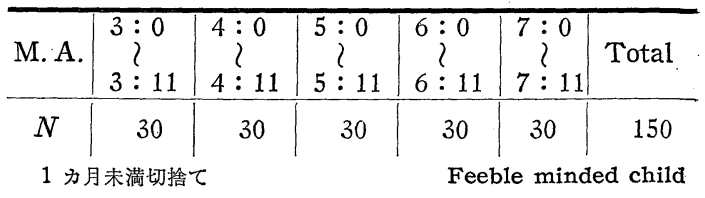

刺激呈示時間は 5 秒. 試行は各 1 回. 3 群とも同じ手 続で連続して実施・

被験者は, 正常児群，精薄児群各 150 名ずつ計 300 名， 内訳は Table 1, 2 の通り.

実験期日は昭和 33 年 1 月より同年 11 月にかけて静 岡市内幼稚園 2 , 保育園 1 , 特殊学級 2 , 精薄児収容施 設 3 力所.

なお，精薄児群は正常児群と同じ暦年令児に怙いては,

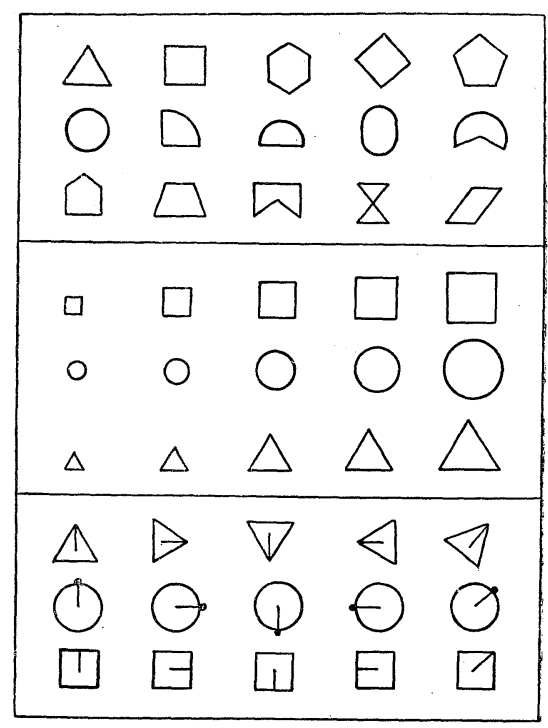

Fig. 1. 
I. Q. が低く，䚾とんど実験不可能であり，かつ後述の 両群比較の観点から精神年令別に被験者を求めたので, M.A. 飞特いては 3 才級より 7 才級までの 30 名ずつ計 150 名であるが，C.A. 別にみると，満 6 才より 15 才 までにまたがり，各年令に括ける人数は多少相違があ る. M. A.は全部「田中びねー式個別テスト」(4)によっ て測定した.

被験者抽出校, 施設

正常児静岡市立安東幼稚園, 同盈進幼稚園, 千代 田保育園

精薄览清水市清水小学校特殊学級, 吉原市伝法小 学校特殊学級, 三島市東小学校, 箱根見晴 学園, 浜名郡浜名寮

\section{III 実 験 結 果}

1.まず両群に扣ける正確選択頻数と正確度を各暦年 令，精神年令別にみると Table 3，4のようになるＭ は正しく選択した図形頻数の平均で各図形群 15 点満点.

Table 3

\begin{tabular}{c|c|c|c|c|c|c}
\hline & C.A. & $3: 0 \sim$ & $4: 0 \sim$ & $5: 0 \sim$ & $6: 0 \sim$ & $7: 0 \sim$ \\
\hline 形 & $\mathrm{M}$ & 13.5 & 14.7 & 14.9 & 15.0 & 15.0 \\
& $S . D$. & 1.33 & 0.81 & 0.39 & 0 & 0 \\
態 & $\%$ & 89.7 & 98.0 & 99.3 & 100 & 100 \\
\hline 大 & $\mathrm{M}$ & 10.1 & 11.3 & 12.6 & 13.8 & 14.6 \\
& $S . D$. & 1.97 & 2.64 & 2.16 & 1.22 & 0.56 \\
小 & $\%$ & 67.3 & 75.3 & 84.0 & 92.0 & 97.3 \\
\hline 方 & $\mathrm{M}$ & 4.6 & 7.8 & 11.1 & 13.5 & 14.1 \\
& $S . D$. & 4.9 & 3.44 & 2.93 & 1.54 & 0.94 \\
向 & $\%$ & 30.7 & 52.0 & 74.0 & 90.0 & 94.0 \\
& & & & \multicolumn{3}{|c}{ Normal child }
\end{tabular}

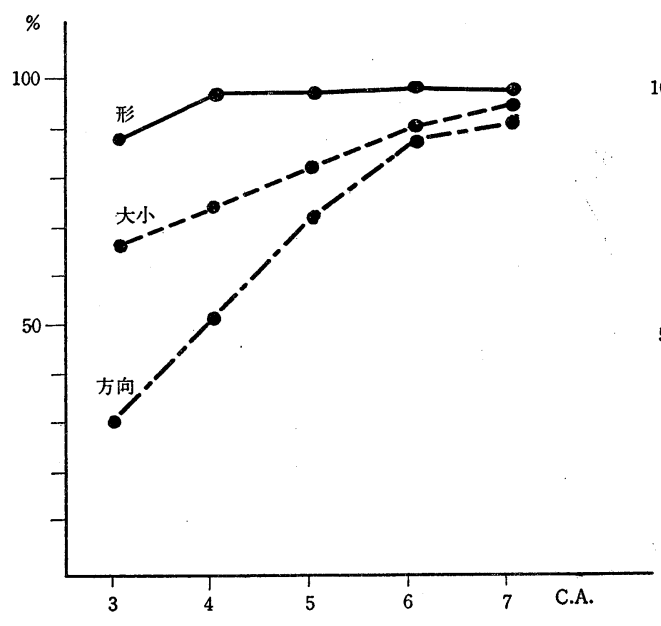

Fig. 2. 正 常 児
正確度 $(\%)$ は正確選択頻数を全選択数で除したもの. 次 にこの両群の発達曲線を描くと Fig. 2，3 のようにな る.

正常児群のカーヴを見ると, その正確度は, 形態群が 最も高く，次に大小, 方向という順になる.この傾向は， 精薄児群に和いても全く同様で，とくに M. A. 3 才〜 5 才に拈いてその差は大きく, 6,7 才になると接近して来 る. しかし, 精薄児の M.A.6,7才級に拈いては, 形態 と大小は接近するが, 方向は、注ぼ同率の差が認められる.

なた，両群のカーヴは，C.A. 和よび M.A. が進むに つれて上昇し 7 才でほぼ 80\% 100\%の範囲内に到達す る点は, 前実験の発達曲線 $(2$, p. 131, Fig.7) と同様で ある・

今この両群の得点を年令, 図形 2 要因から分散分析し てみると, Table 5，6 のようになる.これによると， 両群とも全体としては, 各年令群間, 図形群間共, 有意

Table 4

\begin{tabular}{c|c|c|c|c|c|c}
\hline & M.A. & $3: 0 \sim$ & $4: 0 \sim$ & $5: 0 \sim$ & $6: 0 \sim$ & $7: 0 \sim$ \\
\hline 形 & $\mathrm{M}$ & 9.4 & 13.8 & 13.4 & 13.8 & 14.0 \\
& $S . D$. & 3.54 & 2.01 & 1.89 & 1.55 & 1.69 \\
態 & $\%$ & 62.7 & 92.0 & 89.6 & 92.0 & 93.3 \\
\hline 大 & $\mathrm{M}$ & 6.5 & 9.9 & 11.6 & 13.4 & 13.6 \\
& $S . D$. & 3.37 & 3.80 & 2.35 & 1.83 & 1.68 \\
小 & $\%$ & 43.3 & 66.0 & 77.3 & 89.3 & 90.7 \\
\hline 方 & $\mathrm{M}$ & 3.2 & 6.8 & 9.3 & 9.7 & 11.2 \\
& $S . D$. & 3.01 & 4.60 & 3.30 & 2.86 & 2.34 \\
向 & $\%$ & 21.3 & 45.3 & 62.0 & 64.7 & 74.7 \\
& & \multicolumn{4}{|c}{ Feeble minded child }
\end{tabular}

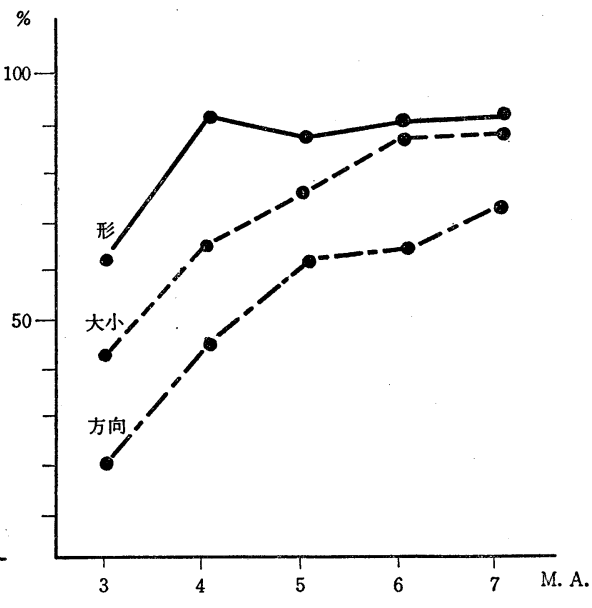

Fig. 3. 精 薄 児 
Table 5 Analysis of variance

\begin{tabular}{|c|c|c|c|c|c|}
\hline Source & d. $f$ & $S . S$. & $M . S$. & $F$ & $\begin{array}{c}\text { Signifi- } \\
\text { cant }\end{array}$ \\
\hline 年 & 4 & 1619.1 & 404.8 & 88.0 & $* *$ \\
\hline 図 & 2 & 1448.0 & 724.0 & 154.4 & $* *$ \\
\hline 交互作用 & 8 & 728.8 & 91.1 & 19.6 & $* *$ \\
\hline 誤 & 435 & 2014.2 & 4.68 & & \\
\hline Total & 449 & 5810.1 & & & \\
\hline
\end{tabular}

Table 6 Analysis of variance

\begin{tabular}{|c|c|c|c|c|c|}
\hline Source & $d . f$ & S. S. & $M . S$. & $F$ & $\begin{array}{c}\text { Signifi- } \\
\text { cant }\end{array}$ \\
\hline M. A. & 4 & 2446.6 & 611.65 & 74.59 & $* *$ \\
\hline 図形 & 2 & 1810.1 & 905.05 & 110.37 & $* *$ \\
\hline 交互作用 & 8 & 227.4 & 28.42 & 3.47 & $*$ \\
\hline 誤 差 & 435 & 3566.2 & 8.20 & & \\
\hline Total & 449 & 8050.3 & & & \\
\hline
\end{tabular}

Table 7 各年令群相互の差

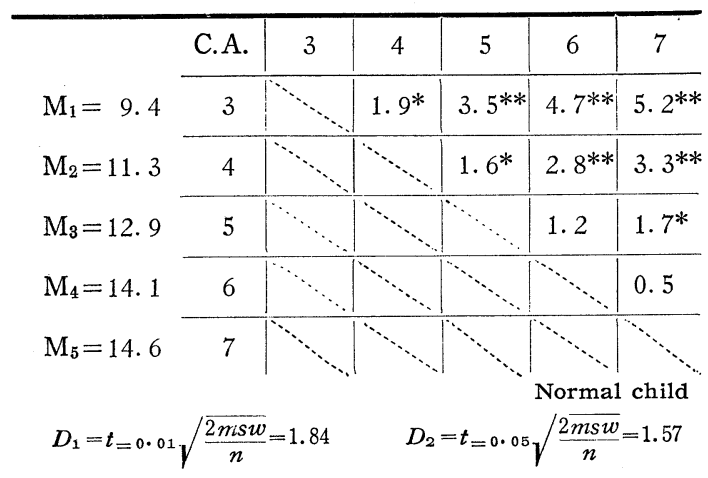

Table 8 各年令群相互の差

\begin{tabular}{|c|c|c|c|c|c|c|}
\hline & M. A. & 3 & 4 & 5 & 6 & 7 \\
\hline $\mathrm{M}_{1}=6.4$ & 3 & & 3. $8^{* *}$ & 5. $2^{* *}$ & $5.9^{* *}$ & $6.5^{* *}$ \\
\hline $\mathrm{M}_{2}=10.2$ & 4 & & & 1.4 & 2. $1^{*}$ & 2. $7^{* *}$ \\
\hline $\mathrm{M}_{3}=11.6$ & 5 & & & & 0.7 & 1.3 \\
\hline $\mathrm{M}_{4}=12.3$ & 6 & & & & & 0.6 \\
\hline $\mathrm{M}_{5}=12.9$ & 7 & & & & & \\
\hline
\end{tabular}

差が認められるが交互作用に和いても有意であるので, 年令階段に和ける上年率と図形群との間は必ずしも平行 せず，交互作用が認められ，図形の属性による難易度も 年令によって異なっていることを物語っている. そこで, 各図形群を通算した各年令群間相互の平均值の間の有意
差を臨界差 $D=t \sqrt{\frac{2 m s w}{n}}$ によって求める(3)と Table 7,8 のようになる.

これによると，正常児に扣いては， 3 才と 4 才， 4 才 と 5 才間には有意差があるが，5才から 7 才までは, 隣 接年令間には差が認められず, とくに精薄児に拉いては, 3,4 才間以降は有意差はない. 勿論隔年間には大部分 1\%ないし $5 \%$ の危険率をもって有意差が認められる.

次に各図形群間相互の有意差を同様の方法で検定して みると全年令段階合計平均では, 各図形群間相互に有意 差が認められたが，発達曲線を見てる明らかなように， 同一年令群のみに和壮る各図形群間の有意差は, 正常児 に拈いては 3 才，4才，5才までは有意であるが，6才， 7 才に拈いては，方向，形態間は有意（危険率 $5 \%$ ）で あっても，形態と大小・大小と方向間は有意差はない. 精薄児群に和いては, 正常児群より図形群間の差は大き く, とくに方向図形群は, どの年令に执いても他群と有 意差をもって低率であり, 形態, 大小間に打いては 5 才 までは差があるが，6，7 才に秥いては有意差は認めら れない.

2. 次に, これらの正確度の正常児, 精薄児両群に拉 ける差を検討してみる. 精薄児群に扣いては前述のよう に，精神年令による各グループであるので，暦年令群の 正常巟と同義的に論ずることは勿論不可能である. しか 乙，精神年令に扬いて正常児と同一水準にある精薄児群 の知覚的反応の正確度が，果して，正常児と如何なる差 を持つか，をた質的に如何なる点が異なるかるみるため に両群を生活年令, 精神年令に括ける同一年令ごとに組 み合わせてその平均を比較してみた. したがってこの年 令段階は 2 つ異質的なカテゴリーによるグループの比 較であるから，ここに根本的な問題点のあることは認め るが，前述のように，正常児の暦年令とその精神年令に おいて同一段階にあると測定された精薄児が正常児とく らべてどの程度の差があるか，技とらく，精神年令にお いて同じでも，本実験のような知覚的選択課題の正確度 に拈いては相当程度劣るものではないか，という予想を 検証するために両群を異なった年令尺度によって直接的 に比較した（この点は，本研究全体を通じての根本問題 であり，C.A. と M.A. を対立させて比較することに

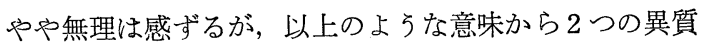
的な年令尺度を便宜的に用いた).

今各年令, 図形群ごとにその平均点の差を $t$ 検定によ って検べると, Table 9 のようになる. 3 図形群とも各 年令通算の平均に拈いては有意差が認められるが，個々 の年令段階に拈いては差のない所もあり，とくに方向図 形に执いては 3 才級より 5 才級まで有意差はなく, また， 大小図形に执いても 4 才級より 6 才級まで同様である. しかし全体として，両群に差の認められたことは，正常 
Table 9 両群間の差

\begin{tabular}{|c|c|c|c|c|c|c|c|}
\hline $\begin{array}{l}\text { C.A } \\
\text { 図形 }\end{array}$ & \multicolumn{2}{|c|}{3} & 4 & . 5 & 6 & 7 & 全 体 \\
\hline \multirow{2}{*}{ 形 態 } & $\mathrm{M}_{1}-\mathrm{M}_{2}$ & 4.1 & 0.9 & 1.5 & 1.2 & 1.0 & 1.6 \\
\hline & $t$ & $5.85^{* *}$ & 2.22 & 4. $05^{* *}$ & $4.28 * *$ & $3.22 *$ & $6.60 * *$ \\
\hline \multirow{2}{*}{ 大 小 } & $\mathrm{M}_{1}-\mathrm{M}_{2}$ & 3.6 & 1.4 & 1.0 & 0.4 & 1.0 & 1.5 \\
\hline & $t$ & 5. $00 * *$ & 1.64 & 1.68 & 0.97 & 3. $03 *$ & $4.05 * *$ \\
\hline \multirow{2}{*}{ 方 向 } & $\mathrm{M}_{1}-\mathrm{M}_{2}$ & 1.4 & 1.0 & 1.8 & 3.8 & 2. 9 & 2. 1 \\
\hline & $t$ & 1.32 & 0.94 & 2.16 & $6.33^{*}$ & $6.30 * *$ & 4.00 ** \\
\hline
\end{tabular}

児に招ける生活年令と, 精神年令が同一段階にある精薄 児の正確度は, 正常児よりやや劣っているという事実を 示している.これは Fig. 2 に特ける両群の正確度カー ヴを比較してみても明らかであるが, 図形の性質によっ て, その差があるものとないものがある点は, 図形の困 難度と知能との関係から生をれて来るものと考えられる が，この点については吟味の余地がある。

3. 以上極めて大まかに, 両群の正確度について比較 してみたが, 次に各個人に拉ける選択の正確度得点と, その個人の知能との間に如何なる関係が存在するか，そ の相関を検討してみる. 全被験者の知能指数执よび知能 偏差值と, 全図形に対する正確度得点との相関係数を, 各年令群別にピアソンの偏差積率法によって求めたもの が Table 10， 11 である.

知能測定は, 正常児の 3 才, 精薄児全員は, 知能指数 により，正常児 4 才より 7 才までは知能偏差値により算 出した.今この $r$ の各年令段階による変化を図示する

Table 10 (知覚 $\times$ 知能) 相関係数

\begin{tabular}{|c|c|c|c|c|c|c|c|c|c|}
\hline C. A. & & 知 覚 & 得 & 点 & I. Q. & \multicolumn{2}{|c|}{ S. S. } & $r$ & Significant \\
\hline $3: 0 \sim$ & $\mathrm{M}$ & $=28.2$ & $S . D$. & $=3.7$ & $M=101.9$ & $S . I$ & 16.5 & 0.80 & $* *$ \\
\hline $4: 0 \sim$ & "1 & 33.9 & "1 & 4.6 & 48.3 & "1 & 8.7 & 0.39 & $*$ \\
\hline $5: 0 \sim$ & $\prime \prime$ & 38.6 & "1 & 3.4 & 45.6 & "1 & 5.8 & 0.39 & * \\
\hline $6: 0 \sim$ & $\prime \prime$ & 42.3 & " & 1.7 & 64.8 & $\prime \prime$ & 6.4 & 0.16 & \\
\hline $7: 0 \sim$ & $\prime \prime$ & 43.7 & " & 0.7 & 53.6 & $\prime \prime$ & 5.7 & 0.16 & \\
\hline
\end{tabular}

C. A. 3: 0 は知能指数平均. $4: 0 \sim 7: 0$ は偏差值 $(S . S$.$) 平均. C.R. =r \sqrt{n-1}>1.96$

Table 11 (知覚 $\times$ 知能) 相関係数

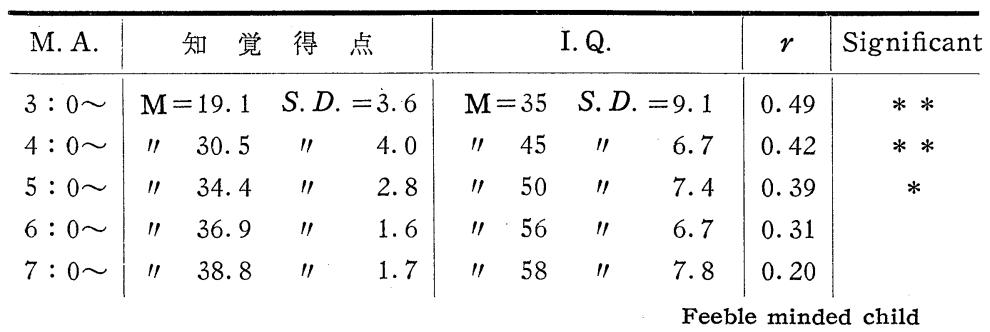

C.A. 3:0 7:0 まで知能指数平均.
と，Fig. 4 のようになる.これによると，正常児では 3 才に拈いて最も高い相関がみられ，4，5才に沶いて 低相関となり，7，8才では認められない。精薄児にお いては，全体として正常児群より相関は低く，M.A. 3 才より6才までにやや認められるが，7才に特いては認 められない.

全体として，曆年令および精神年令の低い段階におい ては, 知能と知覚の正確度との間に相関が認められるが. 年令が進むにつれて相関は低くなり，C. A., M. A. こ.も 6, 7 才級ではほとんど相関は認められないといいうる。

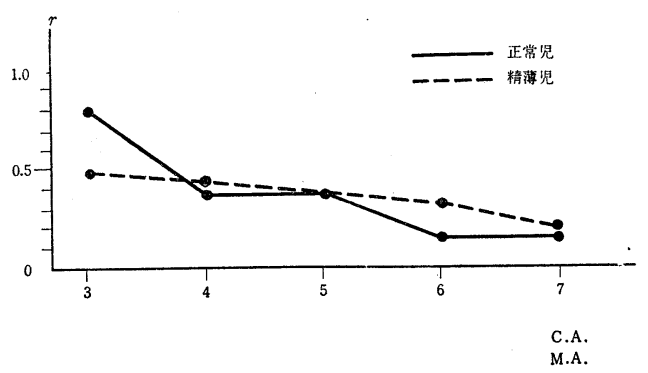

Fig. 4.

この事実は，本実験のようなごく簡単な知覚的選択課 題に招沙る正確度に扣いては, 暦年令の比較的低い幼児 および，精神年令の低い段階の精薄児においては，知能 が強い要因となって働くが，暦年令および精神年令が進 むにつれて，知能因子は低くなるということを一応予測 させ得るが，この他多くの要因の働くことが明らかなの でこの結果のみから断言することは問題があろう.

次に, 以上述べた相関は, 3 群の 図形合計の得点によるものであるが， 前述のように，各図形群の特質によ ってその正確度は明瞭に異なってい る.これは「同じ図形を選べ」とい 5 instruction に対して幼児が選択 する場合,「同じ」の具体的意味が, “かたち”“大小” “方向”の図形の 性質によって異なり, 図形の認知に 特ける困難度がそれぞれ 3 属性によ って異なるためと思われる. そこで 今, 3 群別の図形に対する正確得点 と, その個人の知能との相関をみる と, Table 12, 13 に示すごとく, 各図形群によって相関は異なってい る. 精薄児群に执いては全般に相関 が低いので，その差は有意とはいえ ないが, 全体的には, 方向図形群が 各年令ともやや相関が高く, 形態と 大小は姫とんど同率である。 
Table 12 (図形群別得点 $\times$ 知能) 相関係数

\begin{tabular}{rl|l|l|l|l|l|l}
\hline C.A. & $3: 0 \sim$ & $4: 0 \sim$ & $5: 0 \sim$ & $6: 0 \sim$ & $7: 0 \sim$ & Total \\
\hline 図形 & & & & & \\
\hline 形 態 & $r=0.69$ & 0.29 & 0.20 & 0.10 & 0.12 & 0.31 \\
大 小 & $\boldsymbol{r}=0.76$ & 0.30 & 0.30 & 0.20 & 0.10 & 0.38 \\
方 向 & $\boldsymbol{r}=0.89$ & 0.45 & 0.53 & 0.18 & 0.21 & 0.59 \\
\end{tabular}

Table 13 （図形群別得点 $\times$ 知能）相関係数

\begin{tabular}{l|l|l|l|l|l|l}
\hline M.A. & $3: 0 \sim$ & $4: 0 \sim$ & $5: 0 \sim$ & $6: 0 \sim$ & $7: 0 \sim$ & Total \\
\hline 図形 & & & \\
\hline 形 態 & $r=0.32$ & 0.36 & 0.31 & 0.21 & 0.29 & 0.30 \\
大 小 & $r=0.37$ & 0.39 & 0.28 & 0.28 & 0.28 & 0.31 \\
方 向 & $\boldsymbol{r}=0.59$ & 0.60 & 0.41 & 0.37 & 0.32 & 0.49 \\
& & & \multicolumn{3}{|c|}{ Feeble minded child }
\end{tabular}

正常児に抢いても同様な傾向がより明瞭に認められ， 方向図形群に和ける相関は，他の 2 群いずれよりも各年 令とも高く, 形態と大小との間には, 差が認められな い.この傾向は正確度に括ける 3 群の関係と対称的な結 果を示している.すなわち，最も正確度の低い，誤りの 多小方向図形群に扮いて, 知能との相関は最も高く, 正 確度の比較的高い形態, 大小図形に扣いては，相関が比 較的低いという傾向が認められる.

このことは図形に拉ける方向の同一認知が形態や大小 に比較して発達が括そく, とくに, 精神発達の遅滞した ものや，年令の低い幼児に扣いては正確な同一方向の認 知が困難で多くの誤りを示すものであることを示してい る.

したがって，低年令の幼児の中でも知能の高い者ほど 一般には誤りの多い力向図形の中にあっても正確な選択 率が高く，相関も高くなるのではなかろろか。

乙かも, この正確度は単に純粋な知覚的弁別力の発達 によって規定されるものではなく, 同一図形選択という 課題場面に対する, 幼児の態度, instruction の理解度, とくに「同じ」ということばの具体的図形に拈ける意味 の理解度等によっても大きく規定されることが, 知能と の相関の比較的高い結果から推察される.

\section{IV 考察}

1. 形態, 大小, 万向の 3 図形群にみられた正確度の 差は, 本実験のような比較的単純かつ明確な差をもった 図形の選択弁別に和ける難易度の発達的一傾向を示する のである、しかし正確度そのものは，比較図形群に扣け る図形相互の相違度すなわち形態図形の質的な相違の程 度, 大小図形に和讨る隣接図形間の step の程度, 方向 図形に打ける角度差等によって変化するすのである。
したがってこの 3 群を比較する場合，これらの図形差を 相対的に一致させた上で比較することが必要であろう。 この点で, 本実験に扮ける正確度の図形差は一般的傾向 というには検討の余地がある。

2. 発達曲線からみると, 本実験の場合各図形によっ て異なるが，異なった正確度をもらつつもほぼ平行した 上昇率を示して打り，かつ全体平均では前実験の上昇率 (2，p. 129，Fig2)とほぼ同傾向である.また精薄児に抹 ける，精神年令尺度による年令的変化をみても，正常览 の曲線ほど明確ではないが，同様な傾向が認められたこ そは知覚の発達曲線を規定する知能的要因について示唆 を与えるものである。

また，図形群の属性によって正確度曲線の性質も明確 に異なり，とくに方向図形の発達曲線は全体的に低率で 発達も遅く 6 才ないし 7 才になって, ほぼ他の曲線に近 づき, 正確度も $80 \%$ 近くなることは, 方向知覚の発達 の一傾向であり筆者と小保内が前論文(1) に特いて発表 したところとほぼ同一結果である。

3. 次に注意すべきことは，これらの正確度の差が単 に図形々のものの知覚的特質, 認知に和ける困難度等に よってのみ規定されるものではなく, 前述の通り, 被験 者の，とくに幼児期にある彼等のテスト場面に対する attitude, instrucion の理解の程度, とくに「同じ図形』 といらことばの実際図形に対する受けとり方，教示の際 のサンプルによる説明に括ける「同一」の概念の本実験 に対する転移の程度等が正しい選択を規定する大きな要 因であることを注意せ褯ばならない。

4. 精神年令によって分けられた, 精薄児の正確度が M. A. が上昇するにつれて上升し, しか子その図形群に よる正確度の差が，正常児のそれと同傾向であることは 前述のように，このような知覚的選択に和ける正確度曲 線を規定する知能の要因が非常に大きいことを示すので はないかと思われ，これは３に述べたこととともに重要 な点であると思われる。

また，精神年令に和いて，正常児の暦年令と同一段階 にあると測定された，精薄坚の正確度が各年令段階とも 正常児より劣っているという事実は注目すべさ点であ る.これは, 根本的には, 知能検查に拉ける精神年令の 尺度そのものにも問題があろろが，精神年令に和いて， 正常児の暦年令々同一段階にある精薄児の知的能力が， 具体的な問題解決場面としての本実験のようなテストに 特いては一般に劣るのではないかということが予想され るが，この点についてはまだ検討すべき点が多い。

5. 知能指数と正確度得点との相関が全体を通じて認 められたことは, 前述の通り知能が正確度決定の一要因 として見逃し得ないことを物語るが，その相関が 3 才よ り 5 才前後までに高く，それ以降では洼とんど認められ ないことは，本実験のような「知覚的選択」に扣いて， 
とくに幼児前期に㐨いてはその知能的要因が比較的大き な役割を占めるが，発達するにしたがって知覚反応は独 立した純粋な反応となり，成人の知覚的反応に近づくの ではないかと思われる．したがって，I.Q. そのものの 低い精薄児に拈いては, 本結果のように, M. A. が進ん でも相関係数は全般的に変化しないのではないかと思わ れる.

6. 最後に，正確度が図形の特質によって異なり，ま た知能との相関が図形群によって異なるということは, 選択の手がかりとしての図形の 3 属性の同一性がその困 難度に扣いて異なり, 発達的にも形態に㧸ける同一の認 知が最も早く形成され, 方向のそれが最も遅いというこ とがいいうるであろう。

また「同じ」ということばの意味をどう理解するか, つまり「同一」の概念が具体的な対象図形に拉いてどの ように把握されたかがこの場合問題である. 一般に幼児 に括ける概念は具体的即物的であるので抽象的な「同一」 の概念が成人のように形成されていない，そこで，「同 じ」ということばの意味は，対象物の具体的性格によっ て強く規定されるわけである. したがって, 図形の同一 の認知が知覚的にも非常に容易なるのと, 困難なものに よって，その正確度が大きくかわって来るのであろう。 この点は instruction の与え方とともに実験操作の問題
として今後の吟味が必要である。

7.な拉今後の吟味点として, 比較図形群の相違度の 変化にともなう正確度の検討, 図形選択の内容の質的な 考察, とくに精薄児に拈ける特質の吟味等が考えられ る.

\section{附 記}

本研究を進めるにあたり種々御助言をいただいた教育 大小保内虎夫教授, 統計処理に対する御教示を受けた本 学中沢正寿助教授执よび実験実施に当って協力を惜しま れなかった本研究室学生皆川幸一君に対して心から感謝 の意を表する次第である。

\section{文献}

1) 勝井晃 - 小保内虎夫 幼児の知覚と行動而一二 次元空間に和ける方向の知覚一教育心理学第 3 集, 1952, 18-24.

2) 勝井晃 図形知覚に拈ける発達曲線 の比較的考 察 1, 心研, 1958, 29, 128-133.

3) Lindquist, E. F. Design and analysis of experiments in psychology and education. Boston: Houghton Mifflin, 1956, Pp. 90-96.

4) 田中寛一 田中びね一式知能検査法一1954 年改 訂版一, 東京 日本文化科学社 昭 33 (1958).

1959. 2. 16. 受稿

\title{
情報伝達順序が対人認知に及ぼす影響*
}

\author{
名古屋大学学習院大学 \\ 東京大学 \\ 一一水原泰介 \\ 詫摩武俊 \\ 肥田野 直東 \\ 洋**_
}

S.E. Asch(1) は，人(P)についての情報を伝達する 場合に，それらの伝達する情報の順序によって，その伝 達の受け手が，その人( $\mathrm{P})$ そついてるつ全体的印象が異 ったものとなることを明らかにしている。そして，この 上うな差異が生ずるのは，初め伝達された情報が受け 手の側に，その情報に適合するような“方向づけ”(direction）を与兄，後に伝達される情報は，この方向づけに 適合するような解釈を受ける傾向があるためであると主

* The Effect of Time Order in Giving Information upon Person Perception.

** Taisuke Mizuhara (Nagoya University), Taketoshi Takuma (Gakushuin University), Tadashi Hidano, and Hiroshi Azuma (University of Tokyo).
張している.これは, 情報伝達順序が印象形成に及ぼす 影響について primacy effect を主張しているものと考 觉れる。

伝達する情報の順序の差異によって，印象がぞのよう に異るかを調べるために Asch が用いたチェック リス トの結果について $\chi^{2}$ 検定を行ってみると, 情報伝達順 序の差異によって有意な差が生じているのは 18 項目の 中， 5 項目である. その中， 4 項目は primacy effect を示しているが, 1 項目は recency effectを示してい る.したがって，このAsch の実駼結果から primacy effect のみを主張することは出来ないと思ら。われわ れの研究はこの点についてさらに検討を加光ることを目 的としている. 